\title{
PERILAKU SOSIAL KEPALA MADRASAH DALAM PELAYANAN PENDIDIKAN DI MADRASAH ALIYAH NEGERI I POHUWATO
}

\author{
Nurul Khairiyah Hulawa ${ }^{1}$, Najamuddin Pettasolong ${ }^{2}$ \\ ${ }^{12}$ Pascasarjana IAIN Sultan Amai Gorontalo \\ Email: Nurkhairiyah@gmail.com
}

\begin{abstract}
ABSTRAK
Artikel ini bertujuan untuk menggali perilaku sosial kepala madrasah dalam pelayanan pendidikan di Madrasah Aliyah Negeri I Pohuwato. Metode yang dunakan dalam penelitian ini adalah kualitatif deskriptif, dengan teknik pengumpulan data melalui observasi, wawancara dan dokumentasi. Hasil penelitian menunjukan bahwa Perilaku sosial kepala madrasah dalam pelayanan pendidikan di MAN 1 Pohuwato ditunjukkan dalam berbagai kegiatan yang difokuskan pada dua aspek yaitu bekerjasama dengan pihak lain untuk kepentingan madrasah dalam hal ini yaitu guru, peserta didik dan komite madrasah. Kepala madrasah berpartisipasi dalam kegiatan sosial kemasyarakatan. Kepedulian kepala madrasah dalam pelayanan pendidikan terhadap masyarakat belum tampak disebabkan sulitnya menemukan fakta di lapangan.
\end{abstract}

Kata Kunci: Perilaku Sosial, Kepala Madrasah, Pelayanan Pendidikan

\begin{abstract}
This article aims to explore the social behavior of madrasa principals in educational services in Madrasah Aliyah Negeri I Pohuwato. The method used in this study is qualitative, with data collection techniques with observation, documentation and interviews. The results showed that the social behavior of madrasah principals in educational services at MAN 1 Pohuwato was shown in a variety of activities focused on two aspects, namely collaborating with other parties for the benefit of the madrasa in this case namely teachers, students and madrasa committees. The madrasa head participates in community social activities. The concern of the headmaster in the education service to the community has not yet appeared due to the difficulty of finding facts in the field.
\end{abstract}

Keywords: Social Behavior, Principal of Madrasah, Educational Services

\section{PENDAHULUAN}

Pendidikan merupakan hal yang wajib dilakukan untuk menciptakan kemajuan. Tanpa adanya pengembangan khususnya dalam pelayanan maka sebuah proses pendidikan hanya akan berjalan di tempat, padahal pendidikan merupakan sebuah proses yang selalu mengalami perubahan dalam waktu yang relatif cepat. Perbaikan layanan pendidikan harus diikuti dan bukan sebaliknya, ditolak. Hal ini merupakan sebuah konsekuensi yang ada dalam proses 
pendidikan yang berorientasi pada kemajuan. ${ }^{1}$ Pelayanan pendidikan tidak lepas dari peran seorang pemimpin dalam hal ini Kepala sekolah/madrasah, seorang pemimpin yang dapat mempengaruhi, memberi teladan dan mengarahkan perilaku anggota masyarakat ke arah tujuan tertentu. ${ }^{2}$

Tantangan kepala madrasah adalah rendahnya minat orang tua dan masyarakat untuk menyekolahkan anaknya di madrasah, layanan yang belum representatif, perencanaan keuangan yang kurang matang, kebijakan pemerintah dan yayasan, adanya program pendidikan gratis, program kerja humas lebih fokus terhadap program internal, pengetahuan orang tua tentang madrasah kurang. ${ }^{3}$ Keefektifan pelayanan pendidikan yang harus dimiliki oleh pemimpin lembaga pendidikan yang ditunjukkan melalui perilaku sosialnya adalah sistem informasi yang biasanya diukur dari perspektif kualitas sistem, kualitas informasi, dan kualitas jasa. Adanya sistem penyebaran informasi dan data yang efektif dan efisien menyebabkan perubahan dalam metode pengelolaan dan cara kerja di berbagai instansi dan organisasi. Tingkat efisiensi dan efektivitas sistem pengerjaan dan metode pengelolaan instansi dan organisasi terus meningkat. ${ }^{4}$

Pendidikan diharapkan pada situasi dan kondisi persaingan ketat, baik dari segi administrasi, fasilitas dan termasuk pelayanan. Kualitas pelayanan tidak hanya dinikmati oleh peserta didik, namun guru dan masyarakat sekitar juga akan menikmati pelayanan pendidikan berkualitas. Lembaga pendidikan yang kurang memperhatikan perilaku sosial kepala madrasah dalam pelayanan pendidikan seiring dengan tuntutan stakeholder akan menyulitkan pelayanan pendidikan. ${ }^{5}$ Kepala madrasah mesti memenuhi sebab-sebab yang mengkondisikan lahirnya akibat yang diinginkan termasuk dalam pelayanan pendidikan. Di sinilah betapa pentingnnya kepala madrasah memiliki kemampuan untuk mengintegralisasikan dalam dirinya perilaku sosial dengan tujuan tercapainya pendidikan secara utuh. ${ }^{6}$

Perilaku sosial kepala madrasah dalam pelayanan pendidikan memiliki hubungan untuk membangun kesadaran warga madrasah. Kepala madrasah harus

\footnotetext{
${ }^{1}$ Buhari Luneto, "Problematika Implementasi Kurikulum 2013 di Kota Gorontalo", dalam Jurnal Irfani IAIN Sultan Amai Gorontalo Volume 12 Nomor 1 Juni 2016, h. 10.

${ }^{2}$ Wahyudi, Kepemimpinan Kepala Madrasah dalam Organisasi Pembelajar, (Alfabeta cv November, 2009), h. 119.

${ }^{3}$ Herson Anwar, Implementation Of Education Management Standard In The Guidance Of Private Islamic High School, dalam Jurnal Pendidikan Islam UIN Sunan Gunung Djati Bandung Volume 4 No. 1 Juni 2018, h. 75.

${ }^{4}$ Herson Anwar, "Penerapan Sistem Informasi Akademik (Siakad) dalam Meningkatkan Layanan Akademik di Prodi MPI", dalam Tadbir: Jurnal Manajemen Pendidikan Islam IAIN Sultan Amai Gorontalo Volume 4, Nomor 1: Februari 2016, h. 7.

5 Muhaimin, Manajemen Pendidikan (Aplikasinya dalam Penyususnan Rencana Pengembangan Sekolah/Madrasah), (cet ke-4; Jakarta: Kencana Prenada Media Group, 2012), h. 23.

${ }^{6}$ Sanusi Uwes, "Karakter Sejarah dan Kegiatan Pendidikan" dalam Jurnal Tarbiyah UIN Bandung Vol. 1, No. 1, Tahun 2012, h.6.
} 
memiliki kesadaran menjalin hubungan sosial secara harmonis dengan warga madrasah melalui tingkahlaku yang baik, berfikir positif kepada orang lain, memiliki rasa empati, suka menolong dan bertangungjawab,dan menghargai berbagai macam pendapat. Semua sifat seperti ini membantu pelayanan pendidikan yang mendorong hidup harmonis dalam lingkungan sosial. ${ }^{7}$

Hasil pengamatan awal di MAN 1 Pohuwato menunjukkan bahwa perilaku sosial kepala madrasah dalam pelayanan pendidikan masih cenderung terbatas karena belum banyak dilakukan aktivitas yang mengarah kepada kepedulian terhadap masalah yang dihadapi oleh masyarakat melainkan lebih difokuskan dalam berbagai kegiatan yaitu bekerjasama dengan pihak lain untuk kepentingan madrasah dalam hal ini yaitu guru, peserta didik dan komite madrasah, Selain itu kepala madrasah terkesan hanya banyak melibatkan diri melalui kegiatan partisipasi sosial kemasyarakatan dan kurang memberikan kontribusi yang berdampak kepada masyarakat luas khususnya terkait dengan pelayanan pendidikan.

\section{PERILAKU SOSIAL KEPALA SEKOLAH}

Perilaku sosial kepala sekolah sebagai perwujudkan dari kompetensi sosial kepala sekolah sebagaimana tertulis dalam Peraturan Pendidikan Nasional Republik Indonesia Nomor 13 Tahun 2007, tentang Standar Kepala Sekolah/Madrasah bahwa kepala sekolah harus: a. Bekerjasama dengan pihak lain untuk kepentingan sekolah/madrasah, b. Berpartisipasi dalam kegiatan sosial kemasyarakatan, dan c. Memiliki kepekaan sosial terhadap orang atau kelompok lain. ${ }^{8}$

Secara lebih terperinci perilaku sosial kepala sekolah dapat diuraikan berikut ini:

1. Bekerjasama dengan pihak lain untuk kepentingan madrasah

Kepala sekolah dalam hal ini dituntut untuk mengembangkan dan mengelola hubungan sekolah/madrasah dengan pihak lain di luar sekolah dalam rangka mendapatkan dukungan ide, sumber belajar, dan pembiayaan sekolah/madrasah. Kerjasama yang dilakukan oleh kepala sekolah dengan pihak lain di sini adalah baik secara internal maupun eksternal. Secara internal dilakukan dengan guru dan peserta didik sedangkan secara eksternal dilakukan dengan komite sekolah dan pemerintah.

\footnotetext{
${ }^{7}$ Maksudin, Pendidikan Karakter Nondikotomik (Upaya Membangun Bangsa Indonesia Seutuhnya) dalam Jurnal Pendidikan Karakter, Lembanga Pengembangan dan Penjaminan Mutu Pendidikan (LPMP) Tahun III, Nomor 2, Juni 2013. h. 145.

${ }^{8}$ Permendiknas, Standar Nasional Pendidikan (SNP) dan Panduan KTSP, (Jakarta: Departemen Pendidikan Nasional Direktorat Jendral Manajemen Pendidikan Dasar dan Menengah Direktorat Pembinaan Sekolah Menengah Atas, 2006), h. 155.
} 
Perilaku sosial kepala sekolah dalam pelayanan pendidikan ditujukan untuk peningkatan kinerja guru dan tenaga kependidikan, serta prestasi belajar peserta didik dapat dideskripsikan sebagai berikut. Pertama, menyertakan guru dalam penataran atau pelatihan untuk menambah wawasannya. Kedua memberikan kesempatan kepada guru untuk meningkatkan pengetahuan dan ketrampilanya dengan belajar ke jenjang pendidikan yang lebih tinggi. Ketiga, menggerakan tim evaluasi hasil belajar peserta didik agar giat bekerja. Keempat,menggunakan waktu belajar secara efektif di sekolah dengan cara mendorong guru untuk memulai dan mengakhiri pembelajaran sesuai waktu yang ditentukan. Kelima, mengoptimasi ruang kerja guru sebagai wahana tukar pengalaman antar sesama mereka demi perbaikan kinerja masing-masing. ${ }^{9}$

Perilaku sosial kepala sekolah juga ditunjukkan dalam rangka melakukan peran dan fungsinya sebagai manajer, kepala sekolah harus memiliki strategi tepat untuk memberdayakan tenaga kependidikan melalui kerjasama kooperatif, memberi kesempatan kepada tenaga kependidikan untuk meningkatkan profesinya, dan mendorong keterlibatan seluruh tenaga kependidikan dalam berbagai kegiatan yang menunjang program sekolah. ${ }^{10}$

Penerapan perilaku sosial kepala sekolah ditunjukkan juga melalui kegiatan manajemen yang pada hakikatnya merupakan suatu proses merencanakan, mengorganisasikan, melaksanakan, memimpin dan mengendalikan tenaga pendidik, tenaga kependidikan dan peserta didik serta mendayagunakan seluruh sumberdaya sekolah/madrasah termasuk stakholders pendidikan dalam rangka mencapai tujuan yang telah ditetapkan. Kepala sekolah menunjukkan perilaku sosial dalam pelayanan pendidikan dengan menerapkan strategi yang tepat untuk meningkatkan profesionalisme tenaga kependidikan di sekolahnya. Menciptakan iklim sekolah yang kondusif, memberikan nasehat kepada warga sekolah, memberikan dorongan serta teladan yang baik kepada seluruh tenaga pendidikan, serta melaksanakan model pembelajaran yang menarik, seperti team leaching, moving class. ${ }^{11}$

Kepala sekolah sebagai leader harus mampu bekerjasama dengan berbagai pihak terutama pada saat memberikan petunjuk dan pengawasan, meningkatkan kemampuan tenaga kependidikan, membuka komunikasi dua arah dan mendelegasikan tugas. Perilaku sosial dalam hal kerjasama dengan pihak lain oleh kepala sekolah sebagai leader akan tercermin dalam sifat-sifat (1) jujur, (2) percaya diri, (3) tanggung jawab, (4) berani mengambil resiko dan keputusan, (5) berjiwa besar, (6) emosi yang stabil, (7) teladan. ${ }^{12}$

\footnotetext{
${ }^{9}$ Sudarwan Daniman dan Khairil, Profesi Pendidikan (Bandung: Alfabeta, 2012), h. 80.

${ }^{10}$ E. Mulyasa, Menjadi Kepala Sekolah Profesional (Jakarta: Remaja Rosdakarya, 2003), h. 103.

${ }^{11}$ Nur Efendi, Islamic Educational Leadership, (Yogyakarta: Klimedia, 2015), h. 99
${ }^{12}$ E. Mulyasa, Menjadi Kepala Sekolah.., h. 115
} 
Kepala sekolah harus memiliki perilaku sosial untuk menjalin hubungan yang harmonis dengan lingkungan, mencari gagasan baru, mengintegrasikan setiap kegiatan, memberikan teladan kepada seluruh tenaga kependidikan di sekolah dan kerjasama dalam mengembangkan model-model pembelajaran yang inovatif. Kepala sekolah sebagai inovator akan tercermin dari perilaku sosialnya melakukan kerjasama dengan pihak lain secara konstruktif, kreatif, delegatif, rasional dan objektif, pragmatis, keteladanan, disiplin, serta adabtabel dan fleksibel. ${ }^{13}$

2. Berpartisipasi dalam kegiatan sosial kemasyarakatan

Partisipasi tersebut dapat dikategorikan: pertama, warga komunitas dilibatkan dalam tindakan yang telah dipikirkan atau dirancang oleh orang lain dan dikontrol oleh orang lain. Kedua, partisipasi merupakan proses pembentukan kekuatan untuk keluar dari masalah mereka sendiri. Titik tolak partisipasi adalah memutuskan, bertindak, kemudian mereka merefleksikan tindakan tersebut sebagai subyek yang sadar. ${ }^{14}$

Partisipasi kepala sekolah sebagai perwujudan perilaku sosialnya yang dilakukan secara sadar dan gotong royong berdasarkan kesepakan bersama untuk mencapai tujuan yang diinginkan. Pengertian ini menggambarkan bahwa partisipasi kepala sekolah sebagai proses aktif dalam pemberian sesuatu baik materi maupun non materi dari kepala sekolah dalam pelayanan pendidikan kepada kelompok masyarakat dalam rangka solusi pemecahan masalah. ${ }^{15}$

Perilaku sosial dapat diterapkan ketika kepala sekolah berhubungan dengan masyarakat. Jiwa sosial yang dimiliki kepala sekolah bisa menambah mitra kerjasama sekolah dengan instansi lain yang merupakan instansi pendidikan maupun non-pendidikan, di samping untuk menambah mitra kerjasama, perilaku sosial ini juga bisa dikembangkan melalui beberapa program sekolah dengan masyarakat. ${ }^{16}$ Perilaku sosial yang dimiliki oleh kepala sekolah terbukti dengan partisipasi masyarakat. Menurut Imron dan Sumarsono partisipasi masyarakat erat kaitannya dengan adanya kerjasama dengan beberapa pihak. Kerjasama dengan beberapa pihak itu tidak hanya dengan instansi pendidikan melainkan dengan banyak instansi untuk mendukung kegiatan yang berada di sekolah. Menurut Zaini, dkk bentuk-bentuk partisipasi masyarakat dalam pelaksanaan program pendidikan di sekolah, berupa keterlibatan anggota komunitas sekolah dalam

\footnotetext{
${ }^{13}$ Ibid, h. 118

${ }^{14}$ Nasdian, Pengembangan Masyarakat (Community Development), (Bogor: Institut Pertanian Bogor, 2006), h. 46.

${ }^{15}$ Ointoe Emyot Reiner \& Isnaeni, Mencipta Gagasan, Mendorong Gerakan (Pengalaman Mendorong Partispasi Publik), (Jakarta: Bumi Aksara, 2011), h.119.

${ }^{16}$ Nova Syafira Ariyanti, Ahmad Yusuf Sobri, Desi Eri Kusumaningrum, "Kepemimpinan Kepala Sekolah dalam Meningkatkan Partisipasi Masyarakat" dalam Jurnal Administrasi dan Manajemen Pendidikan, Universitas Negeri Malang, Volume 1, Nomor 1 Maret 2018, h. 2.
} 
pengambilan keputusan, baik mulai dari perencanaan, pelaksanaan program sekolah sampai evaluasi program sekolah. ${ }^{17}$

3. Memiliki kepekaan sosial terhadap orang atau kelompok lain

Memiliki kepekaan sosial terhadap orang atau kelompok lain, indikatornya antara lain berperan sebagai problem finder dilingkungan sekolahan, kreatif dan mampu menawarkan solusi, melibatkan tokoh agama, masyarakat dan pemerintahan, bersikap obyektif/tidak memihak dalam menyelesaikan konflik internal, mampu bersikap simpatik/tenggang rasa terhadap orang lain dan mampu bersikap empati kepada orang lain. ${ }^{18}$

Kepekaan sosial merupakan salah satu indikator perilaku sosial yang ditunjukkan oleh kepala sekolah dalam pelayanan pendidikan. Dengan kata lain kepedulian sosial terwujud dari adanya dorongan perasaan bertanggung jawab dari kepala sekolah atas kesulitan yang dihadapi oleh orang lain. Hal ini merupakan nilai penting harus dimiliki oleh semua orang karena sejatinya manusia adalah makhluk sosial yang tidak pernah bisa hidup sendiri.

\section{METODE PENELITIAN}

Jenis penelitian ini adalah kualitatif deskiptif yang berupaya memberikan analisis tentang masalah yang diteliti dengan tidak tebatas pada pengumpulan dan penyingkapan fakta semata, melainkan hingga pada taraf analisis dan interpretasi data. Adapun teknik pengumpulan data dalam penelitian ini yakni observasi, wawancara dan dokumentasi.

\section{PERILAKU SOSIAL KEPALA SEKOLAH DALAM PELAYANAN PENDIDIKAN DI MAN 1 POHUWATO}

Perilaku sosial kepala MAN 1 Pohuwato sudah sesuai dengan Peraturan Pendidikan Nasional Republik Indonesia Nomor 13 Tahun 2007, tentang Standar Kepala Sekolah/Madrasah yang mencakup dua aspek yaitu kerjasama kepala madrasah dengan pihak lain untuk kepentingan madrasah, partisipasi kepala madrasah dalam kegiatan sosial kemasyarakatan, dan kepekaan sosial kepala madrasah terhadap orang atau kelompok lain.

Berdasarkan hasil wawancara dengan kepala madrasah ditemukan dua perilaku sosial yang dijadikan pembahasan dalam penelitian ini yaitu bekerjasama dengan pihak lain untuk kepentingan madrasah dalam hal ini yaitu guru, peserta didik dan komite madrasah, Selain itu kepala madrasah berpartisipasi dalam kegiatan sosial kemasyarakatan yang telah dilakukannya selama menjabat sebagai

\footnotetext{
${ }^{17}$ A. Imron, dan R. Sumarsono B., Manajemen Hubungan dan Partisipasi Masyarakat, (Malang: Universitas Negeri Malang, 2017), h. 51.

${ }^{18}$ https://www.mbahguru.co.id/2019/11/program-kegiatan-sosial-kepala-sekolah.html
} 
kepala madrasah sebagai bentuk pelayanan pendidikan. ${ }^{19}$ Kepala madrasah MAN 1 Pohuwato tampaknya telah menampilkan perilaku sosialnya dalam pelaksanaan tugas dan tanggungjawabnya dalam melayani pihak lain di bidang pendidikan khususnya yang berkaitan dengan tugasnya baik secara internal maupun eksternal untuk memudahkan pencapaian tujuan pendidikan yang sudah ditetapkan.

Secara lebih sistematis pembahasan hasil penelitian ini maka dapat dikemukakan di bawah ini:

1. Bekerjasama dengan pihak lain untuk kepentingan madrasah

Perilaku sosial kepala madrasah dalam pelayanan pendidikan yang ditunjukkan dalam menjalin kerjasama dengan pihak lain menjadi penting karena ditujukan untuk kepentingan madrasah. Jalinan kerjasama yang sangat bagus antara kepala madrasah dengan bawahannya/guru, kepala madrasah dengan komite madrasah, dan kepala madrasah dengan peserta didik dalam mendukung program yang terdapat di madrasah ini baik akademik maupun non akademik.

Secara lebih detail kerjasama yang dibangun oleh kepala madrasah dengan pihak lain dapat dikemukakan di bawah ini:

a. Kerjasama dengan guru

Dalam pengambilan keputusan kepala madrasah selalu memberikan kesempatan kepada bawahannya yakni guru untuk saling mengeluarkan pendapatnya masing-masing, sehingga keputusan di madrasah selalu dibuat secara bersama. Pengambilan keputusan dilakukan pada saat rapat dengan Dewan Guru terkait dengan kebijakan yang akan diambil oleh kepala madrasah terutama dalam menyusun program madrasah.

Perilaku sosial kepala madrasah ditunjukkan melalui kemampuan komunikasi interpersonal dan proses pengambilan keputusan yang tepat sehingga memberi dampak positif terhadap kinerja guru. Perilaku sosial kepala madrasah tidak hanya ditunjukkan ketika memberikan pengarahan dan pengawasan saja kepada guru, namun juga mampu mengambil keputusan dan mengkomunikasikan hal-hal yang penting guna menciptakan suasana kerja yang kondusif dan dinamis dengan guru yang menjadi bawahannya.

Perilaku sosial kepala madrasah dalam pengambilan keputusan tampak dari tindakannya membagi tugas kepada setiap guru yang menurutnya mampu dan meguasai tugas tambahan yang diberikan kepala madrasah karena MAN 1 Pohuwato ini sudah menerapkan manajemen berbasis madrasah maka di sini kepala madrasah terus menjalin kerjasama yang baik dengan pihak lain untuk kepentingan madrasah atau kemajuan madrasah. 2019.

${ }^{19}$ Tanti Taha Maya, Kepala MAN 1 Pohuwato, Wawancara, Pohuwato, 2 September 
Perilaku sosial penting diteladankan kepada guru bukan saja dengan tindakan yang baik namun juga dengan perkataan yang baik dalam komunikasi dengan guru dalam pengambilan keputusan misalnya saat rapat sehingga suasana yang demikian itu pada giliranya mampu mendorong semangat berkarya guru yang pada gilirannya dapat memacu kinerjanya dalam melaksanakan tugasnya sebagai pendidik.

Hal ini dibenarkan oleh guru bahwa kepala madrasah berani dalam mengambil keputusan sebagai perilaku sosial dengan guru karena banyak pemimpin yang menunda untuk melakukan pengambilan keputusan. Bahkan ada pemimpin yang kurang berani mengambil keputusan. Cara kepala madrasah dalam pengambilan keputusan adalah dilakukan secara individu, kelompok, tim atau panitia, dewan, komisi, mengajukan usul tertulis dan lain sebagainya terutama yang terkait dengan guru. Kerjasama kepala madrasah dengan guru ditekankan pada peningkatan kinerja guru dengan mendorong kemampuan dan keterampilan berdasarkan kewenangan yang dimilki dalam tugas pokoknya, yaitu keterampilan mengajar dalam proses pembelajaran yaitu merencanakan, melaksanakan, dan menilai hasil belajar. ${ }^{20}$ Secara faktual terlihat khususnya dalam rapat tindakan kepala madrasah dalam proses pengambilan keputusan yang dilaksanakannya dilakukan dengan adanya tahap-tahap yakni observasi, pengumpulan data, perencanaan dan mengidentifikasikan masalah berkaitan dengan pendidikan di madrasah, kemudian melakukan musyawarah di antara guru-guru, untuk mengambil suatu kebijakan atau keputusan. Jika sudah disepakati maka konsisten dilakukan dengan melibatkan pihak yang terkait sehingga tidak menjadi sulit untuk diberikan pembinaan dan pengawasan oleh kepala madrasah.

Dari uraian di atas terlihat dengan jelas bahwa perilaku sosial kepala madrasah ditunjukkan dengan melakukan kerjasama dengan pihak lain khususnya guru berupa tindakan dan perkataan yang mendorong guru untuk mengambil keputusan sebagai program madrasah. Keputusan tersebut dilakukan sebagai upaya untuk meningkatkan kinerja guru dalam melaksanakan tugasnya sebagai pendidik dan pengajar dalam pembelajaran.

b. Kerjasama dengan Komite Madrasah

Pengamatan penulis selama berada di lokasi penelitian dalam mengamati perilaku sosial kepala madrasah ditunjukkan oleh aktivitasnya yang selalu mengundang komite madrasah untuk mengikuti rapat mengenai program yang telah dibuat di madrasah dengan tujuan agar komite madrasah dapat menentukan kebijakannya untuk kemajuan madrasah. Komite madrasah telah memberikan pertimbangan terhadap kepala madrasah telah ditunjukkan dengan memberikan

${ }^{20}$ Fathan Detu, Guru Akidah Akhlak MAN 1 Pohuwato, Wawancara, Pohuwato 2 September 2019. 
masukan terkait program kerja madrasah jangka panjang dan jangka pendek, merancang Rencana Kerja dan Anggaran Madrasah, pengadaan sarana dan prasarana madrasah serta memecahkan masalah pendidikan di madrasah dan kepala madrasah merespon pertimbangan dari komite madrasah.

Sementara memberi pertimbangan dalam perencanaan proses pembelajaran yang terkait rancangan dokumen satu kurikulum 2013 selama ini belum pernah dilakukan dan selama ini pula komite madrasah tidak pernah memberikan pertimbangan atau masukan terhadap pembelajaran, karena komite madrasah telah mempercayakan kegiatan tersebut kepada guru yang bersangkutan. Belum diterapkannya dengan baik peranan tersebut dipengaruhi oleh kurangnya wawasan tentang organisasi komite madrasah yang memiliki kewenangan dalam hal pemberian pertimbangan terhadap proses pembelajaran.

Kurangnya wawasan tersebut sebagaimana dikemukakan oleh kepala madrasah bahwa kurangnya wawasan tentang organisasi komite madrasah, menghambat kerjasama kepala madrasah dengan pihak komite madrasah dalam pendidikan. Hal ini mempengaruhi cara pandang dan cara berpikir pengurus komite madrasah dalam melaksanakan tanggungjawabnya. Seperti dalam program kerja komite madrasah banyak kegiatan kurang menyentuh proses pembelajaran. Padahal hal ini merupakan kunci dihasilkannya output pembelajaran yang berkualitas. Hal ini lebih dikarenakan karena kurangnya pengetahuan tentang penerapan peranan tersebut. Sehingga adanya pengurus Komite Madrasah yang tidak melaksanakan tugasnya juga dipengaruhi kurangnya wawasan di bidang keorganisasian, khususnya organisasi komite madrasah. ${ }^{21}$

Komite madrasah telah memberikan pertimbangan kepada kepala madrasah dalam rangka pengembangan kurikulum muatan lokal, dan meningkatkan proses pembelajaran yang menyenangkan kendati diakui masih sangat terbatas. Akibatnya, selama ini kurang terjalin kerjasama dan koordinasi antara pihak komite madrasah dengan kepala madrasah. ${ }^{22}$

Berdasarkan pendapat informan di atas, terkait dengan kerjasama kepala madrasah dengan komite madrasah sebagai orang yang duduk sebagai pengurus mempunyai peranan membantu penyelenggaraan pembelajaran berkualitas dengan memberi pertimbangan dan pemikiran dalam mengoptimalkan upaya peningkatan mutu pendidikan, dan memberikan pemahaman kepada masyarakat terutama orang tua tentang program pembelajaran yang dilaksanakan oleh madrasah dengan mengacu pada standar pelayanan minimal meliputi: kurikulum, peserta

\footnotetext{
${ }^{21}$ Tanti Taha Maya, Kepala MAN 1 Pohuwato, Wawancara, Pohuwato: 9 September 2019.

${ }^{22}$ Amran Andjulangi, Ketua Komite MAN 1 Pohuwato, Wawancara, Pohuwato: 9 September 2019.
} 
didik, ketenagaan, sarana, organisasi, pembiayaan, manajemen madrasah, dan peran serta masyarakat.

Data ini menunjukkan tentang pemahaman terhadap Kepmendiknas Nomor 044/U/2002 Tentang Dewan Pendidikan dan komite madrasah masih kurang, sebagian pengurus komite madrasah tidak memahami isi dan cara menerjemahkan dalam bentuk kinerja. Data ini dapat ditarik kesimpulan sementara bahwa komite madrasah telah melakukan kerjasama dengan kepala madrasah namun belum optimal karena dalam menerapkan peranannya berdasarkan intuisi dan pengalaman saja. Tidak didasarkan pada landasan hukum yang telah dibuat pemerintah.

Pendapat kepala madrasah di atas, setelah dilakukan studi dokumen berupa notulen rapat antara komite madrasah dan kepala madrasah yang menunjukkan bahwa pihak madrasah tidak melakukan pertemuan secara rutin dengan komite madrasah. kepala madrasah yang diwawancarai peneliti mengakui belum rutin melakukan pertemuan untuk menumbuhkan partisipasi komite madrasah dalam pelaksanaan pembelajaran sehingga terjadi kerjasama yang baik di madrasah ini.

Pendapat di atas, dibenarkan oleh ketua komite madrasah bahwa faktor kesibukan pribadi dari masing-masing pengurus cukup menghambat proses kerja komite madrasah selama ini. Kesibukan ini berimbas kepada pengawasan dan pertemuan rutin atau dalam mensosialisasikan program kerja selanjutnya. Karena kehadiran pengurus madrasah dalam rapat-rapat sangat penting, karena rapat-rapat tersebut membahas tentang program kerja. Jika mereka tidak hadir maka menghambat jalannya kegiatan yang dilaksanakan. ${ }^{23}$

Berdasarkan pendapat informan di atas, dapat dikatakan bahwa faktor kesibukan pengurus komite madrasah yang menjadi penghambat dalam kerjasama antara kepala madrasah dengan pihak komite madrasah. Dengan adanya kesibukan tersebut pengurus komite madrasah maupun kepala madrasah terkadang masih kurang melakukan pertemuan kendati pun keberadaannya sangat dibutuhkan pada saat itu.

c. Kerjasama dengan peserta didik

Kepala madrasah adalah guru yang mendapat tugas tambahan sebagai kepala madrasah. Meskipun sebagi guru dengan tugas tambahan kepala madrasah merupakan orang paling bertanggung-jawab terhadap pelaksanaan pendidikan termasuk peserta didik. Dengan tugas tambahan berarti tugas pokok kepala madrasah tersebut adalah guru yaitu sebagai tenaga pengajar dan pendidik. Kepala madrasah bekerjasama dengan peserta didik terlihat dari upayanya selama ini sehingga peserta didik ikut berperan dalam kemajuan madrasah dengan selalu memberi arahan kepada peserta didik dan menasehatinya. Bahkan jika terjadi

\footnotetext{
${ }^{23}$ Amran Andjulangi, Ketua Komite MAN 1 Pohuwato, Wawancara, Pohuwato: 16 September 2019.
} 
pelanggaran tata tertib yang dilakukan oleh peserta didik maka kepala madrasah tidak sekedar memberikan tugas membimbing kepada guru melainkan langsung turun tangan untuk menasehati peserta didik yang melakukan pelanggaran.

Perilaku sosial kepala madrasah dengan peserta didik melakukan kerjasama sesuai hasil pengamatan yang ditunjukkan pada tabel berikut:

Tabel: 1

Kerjasama Kepala MAN 1 Pohuwato Dengan Peserta Didik

\begin{tabular}{|c|l|l|}
\hline No & \multicolumn{1}{|c|}{ Bentuk Kegiatan } & \multicolumn{1}{c|}{ Hasil Pengamatan } \\
\hline 1 & $\begin{array}{l}\text { Pembentukan Forum Anak } \\
\text { Kecamatan tahun 2019 }\end{array}$ & $\begin{array}{l}\text { Memfasilitasi dan mendampingi peserta } \\
\text { didik pada kegiatan Pembentukan Forum } \\
\text { Anak Kecamatan }\end{array}$ \\
\hline 2 & $\begin{array}{l}\text { Pembentukan Pengurus Forum } \\
\text { Anak Daerah Panua }\end{array}$ & $\begin{array}{l}\text { Mengutus peserta didik calon pengurus } \\
\text { Forum Anak Daerah Panua }\end{array}$ \\
\hline 3 & $\begin{array}{l}\text { Pemberian Tablet Tambah } \\
\text { Darah Remaja Putri }\end{array}$ & $\begin{array}{l}\text { Menyiapkan lokasi dan sasaran kegiatan } \\
\text { kerjasama dengan puskesmas Paguat }\end{array}$ \\
\hline 4 & $\begin{array}{l}\text { Sosialisasi Maba Akademi Gas } \\
\text { dan Minyak Balongan dan } \\
\text { STIKES Bakti Nusantara } \\
\text { Gorontalo }\end{array}$ & $\begin{array}{l}\text { Kerjasama dengan pihak perguruan tinggi } \\
\text { terkait penerimaan mahasiswa baru }\end{array}$ \\
\hline 5 & $\begin{array}{l}\text { Kegiatan Rohis dan Buku } \\
\text { Sholat }\end{array}$ & $\begin{array}{l}\text { Menghimbau dan menggerakkan kegiatan } \\
\text { Rohis dan penggunaan buku sholat } \\
\text { sebagai kontrol terhadap peserta didik }\end{array}$ \\
\hline 6 & $\begin{array}{l}\text { Hijratur rasul dan Maulid } \\
\text { Mengerahkan peserta didik mengikuti } \\
\text { kegiatan hari besar Islam baik sebagai } \\
\text { peserta, panitia, maupun pengisi acara }\end{array}$ \\
\hline
\end{tabular}

Sumber Data: Lembar Observasi, 2019

Kepala madrasah pernah memfasilitasi dan mendampingi pada kegiatan Pembentukan Forum Anak Kecamatan dan mengutus calon pengurus Forum Anak Daerah Panua sebagai bukti kerjasama kepala sekoah dengan peserta didik dalam setiap even daerah ini. Perilaku sosial yang ditunjukkan oleh kepala madrasah dengan memberikan motivasi dan dukungan pada setiap kegiatan yang melibatkan peserta didik sudah tidak dapat dibantah lagi. ${ }^{24}$ Perilaku sosial lainnya dari kepala madrasah dalam kerjasama dengan peserta didik dijelaskan informan bahwa di antaranya telah menyiapkan lokasi dan peserta didik dalam kerjasama dengan puskesmas Paguat untuk program pemberian tablet tambah darah remaja putri dan

${ }^{24}$ Husain Hagulo, Peserta Didik Kelas X MAN 1 Pohuwato, Wawancara, Pohuwato: 16 September 2019. 
memberian informasi dan sosialisasi penerimaan mahasiswa baru yang diadakan setiap tahunnya dari perguruan tinggi yang melibatkan peserta didik kelas XII. ${ }^{25}$

Sejalan dengan penjelasan peserta didik di atas bahwa kepala madrasah selama ini selalu menghimbau dan menggerakkan peserta didik untuk mengikuti kegiatan Rohis dan mengaktifkan penggunaan buku sholat sebagai kontrol terhadap peserta didik. Kepala madrasah juga telah mengerahkan peserta didik dalam mengikuti kegiatan hari besar Islam baik sebagai peserta, panitia, maupun pengisi acara yang diadakan oleh madrasah. ${ }^{26}$ Kerjasama dengan pihak lain terwujud dari kerjasama dengan guru, peserta didik, dan komite madrasah. Kepala madrasah mampu menempatkan diri di dalam kelompok kerja dan menjalin komunikasi yang mampu menciptakan kepuasan kedua belah pihak.

2. Berpartisipasi dalam kegiatan sosial kemasyarakatan

Kepala madrasah ikut dalam kegiatan sosial kemasyarakatan dan kegiatankegiatan sosial di MAN 1 Pohuwato ini sudah bagus seperti di MAN 1 Pohuwato ini sudah diadakan jumat beramal yang dilakukan pada setiap minggu sekali. Hal ini dilakukan dengan tujuan apabila ada peserta didik yang membutuhkan maka guru maupun kepala madrasah membantu peserta didik dengan menggunakan dana. Kepala madrasah telah mengisi kegiatan sosial kemasyarakatan seperti peringatan HUT RI ke 74, peringatan hari Bapak Pandu se-Dunia, kegiatan puskesmas paguat, forum generasi bersih dan sehat dan kegiatan donor darah. Bentuk kerjasama pada kegiatan sosial kemasyarakatan dilakukan dengan berbagai cara baik menghadiri kegiatan, mengutus peserta didik, menerima kunjungan tim, melakukan sosialisasi, dan melaksanakan kegiatan.

Partisipasi kepala MAN 1 Pohuwato dengan pihak lain dalam melakukan kegiatan sosial kemasyarakatan dilihat pada tabel berikut:

Tabel: 2

Partisipasi Kepala MAN 1 Pohuwato

dalam Kegiatan Sosial Kemasyarakatan

\begin{tabular}{|c|l|l|}
\hline No & Bentuk Kegiatan & \multicolumn{1}{c|}{ Hasil Pengamatan Kerjasama } \\
\hline 1 & Peringatan HUT RI & $\begin{array}{l}\text { Menghadiri kegiatan Alumni Pemuda } \\
\text { ke-74 }\end{array}$ \\
& & $\begin{array}{l}\text { Peduli Alam dalam pencanangan } \\
\text { penanaman pohon di pegunungan lintas } \\
\text { desa Buhu Jaya, Sipayo dan Soginti } \\
\text { tanggal 16-17 Agustus 2019 }\end{array}$ \\
& & \\
\hline
\end{tabular}

${ }^{25}$ Andika Putra Inaku, Peserta Didik Kelas XII MAN 1 Pohuwato, Wawancara, Pohuwato: 16 September 2019.

${ }^{26}$ Stepiyanti Teyedi, Peserta Didik Kelas XI MAN 1 Pohuwato, Wawancara, Pohuwato: 16 September 2019. 


\begin{tabular}{|c|l|l|}
\hline 2 & $\begin{array}{l}\text { Peringatan Hari } \\
\text { Bapak Pandu Se- } \\
\text { Dunia }\end{array}$ & $\begin{array}{l}\text { Menghadiri apel besar serta melakukan } \\
\text { studi banding pramuka di pangkalan } \\
\text { SMA Negeri 1 Mananggu 23 Februari } \\
2019\end{array}$ \\
\hline 3 & $\begin{array}{l}\text { Kegiatan } \\
\text { Puskesmas Paguat }\end{array}$ & $\begin{array}{l}\text { Menerima kunjungan tim puskesmas } \\
\text { untuk memberikan vitamin khusus siswi } \\
\text { setiap awal bulan }\end{array}$ \\
\hline 4 & $\begin{array}{l}\text { Forum Generasi } \\
\text { Bersih dan Sehat }\end{array}$ & $\begin{array}{l}\text { Sosialisasi terkait dengan pembentukan } \\
\text { Forum Generasi Bersih dan Sehat di } \\
\text { Hotel Golden Sri Marisa tanggal 3 } \\
\text { September 2019 }\end{array}$ \\
\hline 5 & Donor Darah & $\begin{array}{l}\text { Melaksanakan kegiatan donor darah di } \\
\text { madrasah kerjasama dengan PMI } \\
\text { Pohuwato pada tanggal 19 Oktober 2019 }\end{array}$ \\
\hline
\end{tabular}

Sumber Data: Lembar Observasi, 2019

Data tersebut menampilkan perilaku sosial kepala madrasah yang ditunjukkan melalui paritisipasinya dalam kegiatan sosial kemasyarakatan misalnya menghadiri kegiatan Alumni Pemuda Peduli Alam dalam kegiatan pencanangan penanaman pohon di lingkungan pegunungan lintas desa Buhu Jaya, Sipayo dan Soginti, Menghadiri apel besar serta melakukan studi banding pramuka di pangkalan SMA Negeri 1 Mananggu, menerima kunjungan tim Puskesmas Paguat untuk memberikan vitamin khusus siswi/perempuan setiap awal bulan, melakukan sosialisasi terkait dengan pembentukan Forum Generasi Bersih dan Sehat di Hotel Golden Sri Marisa, dan melaksanakan kegiatan donor darah di madrasah kerjasama dengan PMI Pohuwato.

Madrasah yang berada di tengah masyarakat dapat dikatakan berfungsi sebagai pisau bermata dua. Mata yang pertama adalah menjaga kelestarian nilainilai yang positif yang ada dalam masyarakat agar pewarisan nilai-nilai masyarakat itu berlangsung dengan baik. Mata yang kedua adalah sebagai lembaga yang dapat mendorong perubahan nilai dan tradisi itu sesuai dengan kemajuan dan tuntutan kehidupan serta pembangunan. Kedua fungsi ini seolaholah bertentangan, namun sebenarnya keduanya dilakukan dalam waktu bersamaan. Dalam menyelesaikan masalah yang ada di MAN 1 Pohuwato ini kepala madrasah bersikap objektif artinya tidak memihak kepada siapapun dan selalu memberi kesempatan kepada setiap bawahannya untuk saling menuangkan pendapatnya. Hal ini dilihat ketika peneliti melakukan observasi di MAN 1 Pohuwato dengan mengikuti rapat rutin. Selain itu, kepala madrasah memberikan arahan kepada bawahannya yang kurang tertib dalam menjalankan kewajibannya seperti penjagaan dan kebersihan. 
Perilaku sosial dapat dilihat pada penilaian kinerja kepala sekolah pada tabel berikut ini:

Tabel: 3

Penilaian Kinerja Kepala Sekolah pada

Aspek Perilaku Sosial di MAN 1 Pohuwato

\begin{tabular}{|c|l|c|c|c|c|c|}
\hline \multicolumn{2}{|c|}{ Penilaian Perilaku Sosial } & 4 & 3 & 2 & 1 & Nilai \\
\hline 1 & $\begin{array}{l}\text { Berpartisipasi dalam kegiatan } \\
\text { sosial kemasyarakatan }\end{array}$ & V & -- & -- & -- & 4 \\
\hline 2 & $\begin{array}{l}\text { Tanggap dan peduli terhadap } \\
\text { kepentingan orang atau kelompok } \\
\text { lain }\end{array}$ & -- & V & -- & -- & 3 \\
\hline & $\begin{array}{l}\text { Mengembangkan dan mengelola } \\
\text { hubungan sekolah/madrasah } \\
\text { dengan pihak lain di luar sekolah } \\
\text { dalam rangka mendapatkan } \\
\text { dukungan ide, sumber belajar, dan } \\
\text { pembiayaan sekolah/madrasah }\end{array}$ & V & -- & -- & -- & 4 \\
\hline
\end{tabular}

Sumber Data: Olahan Penilaian Kinerja Kepala Sekolah

Hasil penilaian kinerja kepala sekolah yang berhubungan dengan perilaku sosial dalam pelayanan pendidikan terdapat nilai yang baik pada aspek kemampuannya berpartisipasi dalam kegiatan sosial kemasyarakatan dan mengembangkan dan mengelola hubungan sekolah/madrasah dengan pihak lain di luar sekolah dalam rangka mendapatkan dukungan ide, sumber belajar, dan pembiayaan sekolah/madrasah. Sedangkan pada aspek perilaku tanggap dan peduli terhadap kepentingan orang atau kelompok lain masih diperoleh nilai yang kurang baik.

\section{KESIMPULAN}

Perilaku sosial kepala madrasah dalam pelayanan pendidikan di MAN 1 Pohuwato ditunjukkan dalam berbagai kegiatan yang difokuskan pada dua aspek yaitu bekerjasama dengan pihak lain untuk kepentingan Madrasah dalam hal ini yaitu guru, peserta didik dan komite madrasah, Selain itu kepala madrasah berpartisipasi dalam kegiatan sosial kemasyarakatan yang telah dilakukannya selama menjabat sebagai kepala madrasah sebagai bentuk pelayanan pendidikan. Adapun kepedulian kepala madrasah dalam pelayanan pendidikan terhadap masyarakat belum tampak disebabkan sulitnya penulis menemukan fakta di lapangan yang berhubungan dengan aspek kepedulian yang berkaitan dengan perilaku sosial kepala Madrasah. 


\section{DAFTAR PUSTAKA}

Abdullah. Sarton, Arten Mobonggi, Najamuddin Petta Solong, Muh. Arif, "Implikasi Teknologi Informasi Komunikasi terhadap Prestasi Belajar Peserta Didik pada Kelompok Mata Pelajaran Agama", dalam Jurnal Ilmiah AL-Jauhari IAIN Sultan Amai Gorontalo Volume 4 No 1, Juni 2019.

Alim. Muhammad, Pendidikan Agama Islam, Upaya Pembentukan Pemikiran dan Kepribadian Muslim, Bandung: Remaja Rosdakarya, 2007.

Alimandan, Sosiologi Ilmu Pengetahuan Berparadigma Ganda Ed. I, Cet. II; Jakarta: Raja Grafindo Persada, 2002.

Anwar. Herson, Implementation Of Education Management Standard In The Guidance Of Private Islamic High School, dalam Jurnal Pendidikan Islam UIN Sunan Gunung Djati Bandung Volume 4 No. 1 Juni 2018.

--------. "Penerapan Sistem Informasi Akademik (Siakad) dalam Meningkatkan Layanan Akademik di Prodi Manajemen Pendidikan Islam Fakultas Ilmu Tarbiyah dan Keguruan IAIN Sultan Amai Gorontalo", dalam Tadbir: Jurnal Manajemen Pendidikan Islam IAIN Sultan Amai Gorontalo Volume 4, Nomor 1: Februari 2016.

Ariyanti, Nova Syafira. Ahmad Yusuf Sobri, Desi Eri Kusumaningrum, "Kepemimpinan Kepala Sekolah dalam Meningkatkan Partisipasi Masyarakat" dalam Jurnal Administrasi dan Manajemen Pendidikan, Universitas Negeri Malang, Volume 1, Nomor 1 Maret 2018.

As-Sabatin. Yusuf, Bisnis Islam dan Kritik Atas Praktis Bisnis Ala Kapitalis, Bogor: Al Azhar Press, 2009.

Assauri. Sofyan, Manajemen Operasi Jasa, Konsultan Senior. LM-Fe-UI, 2002.

Baron dan Byrne dalam Dendibati Nova, Perilaku Sosial, Blog Denbati Nova,

Basri. Hasan, Kepemimpinan Kepala Sekolah, Bandung: Pustaka Setia, 2014.

Efendi. Nur, Islamic Educational Leadership, Yogyakarta: Klimedia, 2015.

Fadhli. Muhammad, Kepemimpinan Kepala Sekolah yang Efektif dalam Menciptakan Sekolah yang Efektif, dalam Jurnal At-Tarbiyah Sumatera Utara: UIN Sumatera Utara, 20162.

Faqih. Aunur Rahim, Bimbingan dan Konseling dalam Islam, Yogyakarta: UII Press, 2001.

Imron, A. dan Sumarsono R., B., Manajemen Hubungan dan Partisipasi Masyarakat, Malang: Universitas Negeri Malang, 2017. 
Jenkins. Richard, Social Identity, Third Edition, United Kingdom: Routledge, 2008.

Luneto. Buhari, "Problematika Implementasi Kurikulum 2013 di Kota Gorontalo", dalam Jurnal Irfani IAIN Sultan Amai Gorontalo Volume 12 Nomor 1 Juni 2016.

--------. "Perkembangan Minat Masyarakat pada Madrasah Aliyah di Kota Gorontalo", dalam Jurnal Pendidikan Islam Nadwa, UIN Walisongo Yogyakarta Vol. 8, Nomor 1, April 2014.

Lupiyadi. Rambat dan A. Hamdani, Manajemen Pemasaran Jasa, Jakarta: Salemba Empat, ed II, 2006

Makmun. Abim Syamsudin, Psikologi Pendidikan, Bandung: Remaja Rosda karya, 2004.

Maksudin, Pendidikan Karakter Nondikotomik (Upaya Membangun Bangsa Indonesia Seutuhnya) dalam Jurnal Pendidikan Karakter, Lembanga Pengembangan dan Penjaminan Mutu Pendidikan (LPMP) Tahun III, Nomor 2, Juni 2013.

Muhaimin. Manajemen Pendidikan (Aplikasinya dalam Penyususnan Rencana Pengembangan Sekolah/madrasah), cet ke-4; Jakarta: Kencana Prenada Media Group, 2012.

-------. Pengembangan Kurikulum Pendidikan Agama Islam: di Sekolah, Madrasah dan Perguruan Tinggi, Jakarta: Raja Grafindo Persada, 2005.

Mulyasa. E., Menjadi Kepala Sekolah Profesional, Bandung: Remaja Rosdakarya, 2011.

------. Uji Kompetensi dan Penilaian Kinerja Guru, Bandung: Remaja Rosdakarya, 2013.

Mustaqim, Abdul, Menjadi Orang Tua Bijak, Bandung: Al Bayan Mizan, 2005.

Nasution. M N, Manajemen Jasa Terpadu, Bogor: Ghalia Indonesia 2004.

Niha, Irma Purnima dan Buhari Luneto, Razak Umar, "Pengaruh Penerapan Program Akademik dan Aplikasi Siakad terhadap Mutu Pelayanan Mahasiswa di FITK", dalam Tadbir: Jurnal MPI Volume 7, Nomor 1: Februari 2019

Permendiknas, Standar Nasional Pendidikan (SNP) dan Panduan KTSP, Jakarta: Dikdasmen, 2006.

Priansa. Donni Juni dan Somad. Rismi, Manajemen Supervisi dan Kepemimpinan Kepala Sekolah, Bandung: Alfabeta, 2014. 
Rahmawati. "Chinese Ways of Being Good Muslim: From The Cheng Hoo Mosque to Islamic Education and Media Literacy", dalam Indonesian Journal of Islam and Muslim Societies IAIN Salatiga Volume 8 Number 2 December 2018.

Sanjaya. Wina, Strategi Pembelajaran Berorientasi Standar Proses Pendidikan, Jakarta: Kencana Prenada Media Group, 2009.

Sidik, Firman. "KONSEP PENGEMBANGAN KURIKULUM PENDIDIKAN ISLAM." (2016): 100-114.

Silastuti, Emaret Perbedaan Perilaku Sosial Siswa Yang Pembelajarannya Menggunakan Model Klarifikasi Nilai dan Konsiderasi dengan Memperhatikan Konsep Diri Pada Pembelajaran PPKn Kelas XI SMK Negeri 2 Bandar Lampung, Tesis; Lampung: PPS Fakultas Ilmu Keguruan dan Pendidikan Universitas Lampung, 2016

Sulistyorini, Manajemen Pendidikan Islam, Yogyakarta: Teras, 2009.

Tjiptono. Fandy, dan Diana Anastasia, Total Quality Service, Yogyakarta: Andi Offset, 2001.

Undang-Undang Nomor 14 Tahun 2015 tentang Guru dan Dosen.

Usman. Husaini, Manajemen Teori Praktik dan Riset Pendidikan, Jakarta: Bumi Aksara, 2008.

Uwes, Sanusi, "Karakter Sejarah dan Kegiatan Pendidikan" dalam Jurnal Tarbiyah UIN Bandung Vol. 1, No. 1, Tahun 2012.

Wahyudi, Kepemimpinan Kepala Sekolah dalam Organisasi Pembelajar, Alfabeta, 2009. 